\title{
"One Can't Live on Air": Sarah McComb and the Problem of Old-Age Income for Single Women Teachers, 1870s-1930s
}

\section{Linda Van Ingen}

Alone in her last phase of life, Sarah McComb copied a poem onto the back of a postcard that read, "And now ... what wait I for? No home, no welcome, nobody who needs me; no love, to which in my loneliness I can turn. And now ... what wait I for?"1 She died in January 1937, not long after she "fell and broke her thigh" the previous December. She was ninety-one years old. Her hospital bills and funeral invoice, like most of her expenses, were sent to her brother's daughter. ${ }^{2} \mathrm{Her}$ old-age dependency on extended kin, however, was not inevitable. As a single, childless, white middle-class woman, Sarah had supported her independence through itinerant teaching, traveling the American west including Alaska, with additional adventures to Guatemala and Cuba. As she approached her sixties, she pursued alternative strategies for income, intensifying her efforts to earn a profit through business ventures while continuing to teach for as long as she could. Despite her determination, Sarah faced old age without savings of her own; she would not be able to finance her independence once she stopped teaching. When that time finally came, she was seventy-six years old and had to turn to her brother for help. Securing his support, however, was a proposition fraught with familial tension and personal anxiety. Although women like Sarah valued their independence, they struggled to carry this independence into old age.

Sarah belonged to the first generation of white educated women who had forgone traditional marriage and children in order to seek

Linda Van Ingen is Associate Professor of History and Director of the Women's \& Gender Studies Program at the University of Nebraska-Kearney; e-mail: vaningenL1@unk.edu. She would like to thank Lore Kuehnert, Trisha Franzen, panelists at the Women \& Gender Historians of the Midwest Conference, and the anonymous reviewers at the History of Education Quarterly for their helpful comments and suggestions. She is grateful to the University of Nebraska-Kearney Research Services Council for financial support for research.

${ }^{1}$ Sarah McComb, Diary, February 1926, in author's possession.

${ }^{2}$ Hospital bills, December 1936 and January 1937; Funeral Director's Invoice, 2 February 1937; file 79, carton 2, Keyes-McIntire-Voorheis-Clark Family Papers, Bancroft Library, University of California, Berkeley (hereafter Keyes papers). 
personal fulfillment outside the home. The proportion of American women sixty-five years or older who never married increased from 5.6 percent in 1890 to 8.1 percent in 1930 . Their actual numbers are more impressive, quadrupling from 66,758 never-married women in 1890 to 268,416 in 1930 . The number of widowed and divorced women sixtyfive years or older, although far fewer, likewise increased over that time span. ${ }^{3}$ Like many of these women, Sarah used resources at her disposal to support her independence and autonomy. She taught for over a decade before a brief companionate marriage that ended in widowhood when she was forty-one years old. Unwilling to marry again, she resumed her career as a teacher for over three decades. However, unlike many well-known independent women of her generation, such as Jane Addams or Florence Kelley, Sarah did not have the financial means through inheritance or a network of wealthy women friends to support her as she aged. ${ }^{4}$ Of the many single women in public roles, Sarah was more like Anna Howard Shaw who not only began young adulthood as a teacher, but was dependent upon her own wages throughout her life. Yet, whereas Shaw earned a pension upon her retirement as a salaried president of the National American Woman Suffrage Association, Sarah not only lacked a pension as a career teacher, she did not earn enough during her most productive years to save for later. ${ }^{5}$ Female teachers earned on average \$52-\$65 per month in 1890, far less than the \$132-\$165 monthly average earned by male teachers. ${ }^{6}$ Limited in income yet steeped in a new culture of female autonomy, teachers like Sarah faced a future of circumscribed options; old age meant a return

${ }^{3}$ Susan B. Carter, Scott Sigmund Gartner, Michael R. Haines, Alan L. Olmstead, Richard Sutch, Gavin Wright, eds., Historical Statistics of the United States: Earliest Times to the Present, Volume 1: Population (New York: Cambridge University Press, 2006), 78-79.

${ }^{4}$ Single women of the same generation as Sarah McComb (1845-1937), such as Jane Addams (1860-1935), Florence Kelley (1859-1932), and Anna Howard Shaw (1847-1919), collectively mark a new generation of female independence. Susan B. Anthony (1820-1906), also a single woman, belonged to an older generation of women leaders who mostly followed traditional patterns of marriage and children. Cemetery card, file 79, carton 2, Keyes papers; Edward T. James, Janet Wilson James, Paul S. Boyer, eds., Notable American Women: A Biographical Dictionary (Cambridge, MA: Belknap Press, 1971).

${ }^{5}$ The National American Woman Suffrage Association raised $\$ 30,000$ to provide Shaw an annual retirement income of $\$ 3,200$ (\$267 per month) beginning in 1916 when she was sixty-eight years old. Ida H. Harper, ed., History of Woman Suffrage, Volume 5: 1900-1920 (New York: Arno Press, 1969), 458; Trisha Franzen, "Singular Leadership: Anna Howard Shaw, Single Women and the US Woman Suffrage Movement," Women's History Review 17, no. 3 (July 2008): 421.

${ }^{6}$ Glenda Riley, Inventing the American Woman: A Perspective on Women's History (Arlington Heights, IL: Harlan Davidson Press, 1987), 167. The pay differential between female and male teachers varied by region and position, with high school teachers, principals, and superintendents-male-dominated positions-earning higher salaries than elementary teachers. See Joel Perlmann and Robert Margo, Women's Work? American Schoolteachers, 1650-1920 (Chicago: University of Chicago Press, 2001). 
to female subjection. Sarah resisted this fate, however, pursuing strategies for income that gave her hope for continued independence. Her experience draws attention to the remarkable, though not uncommon, educated women who faced old-age dependency before the establishment of pension plans and social security.

Most teachers in the United States were single women. In 1900, women held 70 percent of the teaching positions, and 95 percent of them were never-married, widowed, or divorced. ${ }^{7}$ Although most women married at some point in their life course, female teachers challenged this pattern, marrying at rates far below the national norm. ${ }^{8} \mathrm{~A}$ rich body of scholarship on women teachers explores both the advantages and disadvantages of the profession, showing how teaching created opportunities for self-expression and autonomy for women but also how the gendered economy depressed their wages, limited their work through marriage bars, and privileged male advancement into the better paid supervisory positions. 9 Studies also show that by the end of the nineteenth century, teaching gave women long-term employment. For example, a study of Boston teachers found that 18 percent of those hired in 1880 worked for over forty-one years. ${ }^{10}$ Many rural teachers also made a career of teaching, often continuing their educations by attending normal schools, colleges, or universities to complete degrees that enabled them to work throughout their adult lives. ${ }^{11}$ Not only were teachers single women, but they increasingly pursued opportunities for lifelong work, teaching well into old age.

Historians employing age as a tool of analysis have explored how a woman's life is shaped by her age. Age is utilized as a "biological reality, a

${ }^{7}$ Jackie M. Blount, Destined to Rule the Scbools: Women and the Superintendency, 1873-1995 (New York: State University of New York Press, 1998), 92.

${ }^{8}$ Christine Ogren, The American State Normal School: "An Instrument of Great Good" (New York: Palgrave, 2005), 193; Barbara Miller Solomon, In the Company of Educated Women (New Haven, CT: Yale University Press, 1985), 31-32, 119-20; Kathleen Underwood, "The Pace of Their Own Lives: Teacher Training and the Life Course of Western Women," Pacific Historical Review 55 (November 1986): 513-30.

${ }^{9}$ Blount, Destined to Rule the Schools; Mary Hurlbut Cordier, Schoolwomen of the Prairies and Plains: Personal Narratives from Iowa, Kansas, and Nebraska, 1860s-1920s (Albuquerque, NM: University of New Mexico Press, 1992), 49; Polly Welts Kaufman, Women Teachers on the Frontier (New Haven, CT: Yale University Press, 1984); Ogren, The American State Normal School; Kathryn Kish Sklar, Catberine Beecher: A Study in American Domesticity (New Haven, CT: Yale University Press, 1973); Solomon, In the Company of Educated Women; Underwood, "The Pace of Their Own Lives;" Kathleen Weiler, Country Schoolwomen: Teaching in Rural California, 1850-1950 (Stanford, CA: Stanford University Press, 1998).

${ }^{10}$ Weiler, Country Schoolwomen, 18.

${ }^{11}$ Kathleen Underwood finds over two-thirds of Colorado State Normal School female graduates in the 1890s came from small towns of less than 5,000 people. Most graduates remained in Colorado, with one-third returning to their small hometowns to teach. She also concludes that teaching gave these women the opportunity to postpone or forego marriage altogether. Underwood, "The Pace of Their Own Lives," 519-21. 
social construct, and a category of difference."12 Although historians of education have shown how young women teachers looked optimistically to their future as they earned needed money before marriage, or have followed women's teaching careers through personal accounts, only recently has age been made an explicit analytical theme. Kay Whitehead and Stephen Thorpe centralize the function of age in their study of an unmarried female teacher in Australia from 1907 to 1947. They demonstrate how age "interacts with other discourse/practices to make a difference across a woman's life," concluding that single women teachers found both opportunities and marginalization as they aged and challenged patriarchal constructs of gender roles. ${ }^{13}$ Older female teachers experienced autonomy and independence as "new women" yet faced discrimination and obstacles that limited their status as educated and experienced workers. ${ }^{14}$

While Whitehead and Thorpe highlight the impact of age on women's work as teachers, Karen Leroux explores the problem of oldage income; women teachers worried about sustaining their independence when they could no longer work. In her study of Chicago teachers in the 1890 s, Leroux shows how women teachers took their concerns for retirement into politics and sought state-sponsored pensions. As single teachers, they could not rely on women's traditional dependency on family, but as wage earners they could not save enough to continue their independence into old age. Likening their role as public servants to pensioned veterans, they asked the state to support their retirement by administering a fund financed by a collective contribution from teachers' wages. State-administered pensions, they explained, would maintain a woman teacher's precarious balance between independence and dependency, allowing them to stay out of the market economy and reducing their reliance on distant relatives. Modest in its demands on the state, however, this pension system failed to meet actuarial criteria for long-term solvency. ${ }^{15}$

${ }^{12}$ Birgitte Søland, “Ages of Women: Age as a Category of Analysis in Women's History, Special Issue," Fournal of Women's History 12, no. 4 (Winter 2001): 6-10; Hilda L. Smith, "Cultural Constructions of Age and Aging: 'Age': A Problematic Concept for Women," Fournal of Women's History 12, no. 4 (Winter 2001): 77-86.

${ }^{13}$ Kay Whitehead and Stephen Thorpe, "The Function of Age and the History of Women's Work: The Career of an Australian Teacher, 1907-1947," Gender \& History 16, no. 1 (April 2004): 172-97.

${ }^{14}$ According to Whitehead, by the late nineteenth century in Australia, "the term 'new woman' had been coined to describe this cohort of well-educated, socially and economically independent single women." Kay Whitehead, The New Women Teachers Come Along: Transforming Teaching in the Nineteenth Century (Sydney: Australian and New Zealand History of Education Society Monograph Series, 2003), 71.

${ }^{15}$ Karen Leroux, "'Unpensioned Veterans': Women Teachers and the Politics of Public Service in the Late-Nineteenth-Century United States," Fournal of Women's 
The problem of old-age income for single women teachers was acute by the 1920s. Abraham Epstein, who served as director of the Pennsylvania Commission to Investigate Old Age Pensions from 1918 to 1927 and who later popularized the term "social security," wrote in 1922 that because of low wages for teachers, saving for old age was "out of the question." He further noted the "obvious fact" that many teachers, especially women teachers, remained unmarried, and "ordinarily, have no one to depend upon in old age." The United States, he wrote, although early on the world stage for public education, "is one of the last to make provision for the care and relief of superannuated and aged teachers." Not only was it a matter of justice, he argued, "to provide our teachers... against the day when they are no longer able to provide for themselves," but a matter of quality in education. "[T] eachers living continuously in the dread of old age," he wrote, "are not the most desirable persons for the instruction and inspiration of our younger generation." Sounding the alarm about aging teachers, he cited a 1917 report that found approximately half of the nation's teachers did not have pensions. ${ }^{16}$

Amidst this growing concern about pensions for teachers, women like Sarah McComb were on their own. How did they solve the problem of old-age income? Because old age has not been a central focus of research, evidence about aging female teachers is sprinkled throughout various studies about teachers in general. In her study of frontier women teachers of the mid-nineteenth century, for example, Polly Welts Kaufman briefly documents the "later life" of a number of single women teachers, such as Rebecca Clark, a native of Massachusetts born in 1830 who taught in Iowa and Wisconsin before spending her last years shuttling between Massachusetts and her brother's home in Kansas. Amy Chapman of New York taught in Ohio but spent her later years teaching freedmen in North Carolina before she died in 1880. Elizabeth Hill, who taught in Missouri and Illinois, likewise ended her career by teaching freedmen in the South until her death in 1868 . Rebecca Veazie of Massachusetts, who taught for three years in Jamaica as part of an itinerant career that also included Ohio, Indiana, Iowa, Kentucky, Virginia, and New Orleans, apparently tried living with relatives but did not find an agreeable situation. She consequently resumed her career, teaching in Florida until her death in 1870. As part of her larger

History 21, no.1 (Spring 2009): 34-62. For more on women's pensions and the emerging welfare state, see Theda Skocpol, Protecting Soldiers and Mothers: The Political Origins of Social Policy in the United States (Cambridge: Harvard University Press, 1992); Linda Gordon, Pitied But Not Entitled: Single Mothers and the History of Welfare, 1890-1935 (New York: The Free Press, 1994).

${ }^{16}$ Abraham Epstein, Facing Old Age: A Study of Old Age Dependency in the United States and Old Age Pensions (New York: Alfred A. Knopf, 1922, 1972), 183-9. 
study of women teachers, Kaufman documents the existence of single women teachers and their dependency on extended kin or continued employment as they grew old. ${ }^{17}$

Kathleen Weiler likewise includes aging single women teachers in her study of country school teachers in California. In her effort to "capture individual life histories," she discovered a short narrative by a single woman teacher who struggled to make ends meet as she aged. Ethel Hall, who was divorced with two children, wrote in 1926 that "More than twenty-five years after" she had "wandered teaching over much of California," she found herself back at her starting point in Pleasant Valley where she hoped to obtain yet another teaching position. She described herself as "old and struggling desperately," a reference not just to her financial straits but to her long-term efforts to obtain a pension, which was based on teachers' contributions and stiff longevity requirements of employment. Hall struggled, she said, "for each successive school to add just that much more to the pension I was determined to get." As Weiler points out, this teacher was only fortyfour years old, but her poverty and looming old age wore her down. Given the fragmentary evidence, it is unknown, according to Weiler, "whether she finally collected her hard-earned pension." 18 Another single woman teacher in Weiler's study, Carrie Barnett, began teaching at age 17 and later supported her sister and nephew. She also owned her own house in a respectable neighborhood. This teacher's sound economic standing, Weiler concludes, came not from her lifelong work as a teacher but from "some inherited wealth." ${ }^{19}$ Unable to earn enough as a teacher, Barnett relied on additional income to support herself as she grew old. This need for additional income was a practical necessity for single women career teachers. Those not positioned to inherit wealth faced especially precarious circumstances as they aged. Yet, this last phase of a teacher's life remains largely untold, buried as lost fragments of history within larger studies of women teachers.

Extant archival material detailing the last decades of Sarah McComb's financial well-being provides a useful biographical study to reclaim this history of aging female teachers. ${ }^{20}$ Like the frontier and country teachers identified by Kaufman and Weiler, Sarah pursued

${ }^{17}$ Kaufman, Women Teachers on the Frontier, 39-40, Appendix D, 230-53.

${ }^{18}$ Weiler, Country Schoolwomen, 147-8.

${ }^{19}$ Ibid., 127.

${ }^{20}$ Drawing on Alice Kessler-Harris's insight about the role of biography in history, this article views Sarah's life "not as a subject to be studied for its own sake, but as evidence that could provide a different path into the past." Jean Quataert and Leigh Ann Wheeler describe Kessler-Harris's observation of "'see[ing] through" an individual life as a window on larger historical questions. David Nasaw similarly reminds historians that biography "is no longer restricted to the lives of the rich, powerful, famous, and infamous," but can also focus on the "unknown" whose stories offer a "fruitful approach to re-examining, and perhaps reconfiguring," categories of analysis "as they interact 
individual options for old-age income. Through her experience, this article explores three income strategies. First, Sarah focused on her career, seeking ways to increase her pay and longevity as a teacher. The longer she worked, the longer she could sustain her independence. Second, she entered into business schemes, hoping for a financial windfall. Extra money would supplement her meager teacher's salary. Finally, Sarah sought support from extended kin, carefully subscribing to norms of propriety for her race and class not only to secure good references for employment as a teacher, but to claim support from her brother. Unlike the collective efforts of urban teachers organizing for pensions, rural teachers like Sarah sought individual solutions for the problem of old-age income.

Sarah's threefold approach produced mixed results, however, since each one of these efforts was shaped and structured by gendered assumptions that privileged male independence; old-age independence was a prerogative for men, not women. As Alice Kessler-Harris argues, economic fairness, including social and legal constructs for workplace benefits, was constructed in ways that kept women subordinate to men. ${ }^{21}$ Yet, Sarah resisted this construct of female dependency. Her individual actions in the teaching, market, and family economies sheds light on the challenges women faced as they aged. In an era of growing expectations for female autonomy, single women teachers marched forward without a safety net. Their history contributes to our understanding about gender and old age in the emerging welfare state.

\section{The Teacher Economy}

Born in Ann Arbor, Michigan, in 1845, Sarah was the eldest of six children in a white, middle-class family. She established a close friendship with her youngest sister, Jennie Voorheis, with whom she maintained

at the level of the individual." Alice Kessler-Harris, "AHR Roundtable: Why Biography?" American Historical Review 114, no. 3 (June 2009): 626; Jean Quataert and Leigh Ann Wheeler, eds., "Editorial Note: Individual Lives: Windows on Women's History," Fournal of Women's History 24, no. 3 (Fall 2012): 7; David Nasaw, "AHR Roundtable: Historians and Biography-Introduction," American Historical Review 114, no. 3 June 2009): 576.

${ }^{21}$ In historicizing the ideas of economic fairness and documenting how these ideas changed over time, Kessler-Harris argues that the social and legal constructs of workplace fairness limited women's access to full citizenship. She identifies the need for economic citizenship, which she defines as the "achievement of an independent and relatively autonomous status that marks self-respect and provides access to the full play of power and influence that defines participation in a democratic society." Women may have had access to work and the ability to support themselves, but economic citizenship "does not end there." It also requires "customary and legal acknowledgment of personhood" with "all that implies" for the "distribution of resources." Alice Kessler-Harris, In Pursuit of Equity: Women, Men, and the Quest for Economic Citizenship in 20tb Century America (New York: Oxford University Press, 2001), 12-13. 
a lifelong correspondence. These letters, her diary, and archival family records document her life well into old age. Sarah began her teaching career soon after graduating from Ann Arbor High School in 1865. As a young woman she had few financial worries as she initially remained within the economic security of her family. When her family moved to Grand Rapids, Sarah moved along with them and taught in the area. She had an adventurous spirit, however. While Jennie never married and stayed home with their parents, Sarah pursued her independence, venturing off to teach in locales both near and far. She continued to teach until her brief marriage in 1882 when she was thirty-seven years old. Widowed several years later, she resumed her career as a single female teacher, unencumbered by family responsibilities. ${ }^{22}$

Teaching gained acceptance as a means of work for women due to its association with women's domestic lives; women were considered naturally capable of working with children and inculcating moral, ethical, and patriotic values as defined by the dominant white, middle-class. Many women, however, saw it as a way to assert their independence and self-worth. Teaching gave them an income of their own and created opportunities for education, travel, and adventure without compromising their status as proper women. In her study of female teachers who graduated from normal schools in the late nineteenth century, Christine Ogren finds that many single women not only supported themselves by teaching, but also "logged a remarkable number of years and a wide variety of experiences" in classrooms throughout the country and beyond. Teachers trained in the east fled "with joy to the West," while others went to "colored schools" in the South or sought a "taste of life on the coast." Many normal-school alumnae in her study traveled out of the country to "Puerto Rico, the Dominican Republic, Mexico, Brazil, Chile, Turkey, Japan, India and other countries." Some also went to Europe to further their educations and broaden their horizons. ${ }^{23}$

Sarah enjoyed these vocational benefits. She took her first big adventure away from home in 1877 when, at thirty-two years old, she secured a two-year teaching position in Guatemala. ${ }^{24}$ This experience expanded her world: she experienced another culture, learned to speak Spanish, and observed the dynamics of commerce when her steamship frequently docked to load and unload coffee, cotton, and cattle. On her return journey, Sarah met her future husband, Jack McComb, the purser of the steamship Granada. When they married, Sarah followed

\footnotetext{
${ }^{22}$ Cemetery card, file 79, carton 2, Keyes papers. Years and locations of teaching positions from Sarah McComb, "Record of Teaching," file 95, carton 2, Keyes papers.

${ }^{23}$ Ogren, The American State Normal School, 195-8.

${ }^{24}$ Although there is no indication that McComb followed the path of a missionary teacher, there is a history of women missionaries going abroad to teach. Ogren, The American State Normal School, 198.
} 
prevailing norms proscribing married women from teaching and set up a household in California. Although Jack supported Sarah while he worked, he did not leave her any property or a means of support upon his death. Theirs had been a companionate marriage, based on love and compatibility rather than property or social class. They shared a love of poetry that blossomed on the steamer when they met and continued into their marriage. When Jack died, Sarah kept passionate letters from him and copied many poems of forlorn love into her diary during her years of widowhood. ${ }^{25}$ Sarah did not lose her adventurous spirit, however, as she subsequently resumed her career in teaching, pursuing jobs in states across the American west and Alaska before venturing to Cuba. When she returned to the United States, she taught across the American west again before settling in California in the 1910s. As she aged, teaching remained her principal source of income.

Getting back into teaching after widowhood was not easy, however. Sarah had taught for over a dozen years before marriage but had been out of the classroom for four years before her husband died. It took her another four years after widowhood to get back into the profession, having initially returned to Michigan to be with her mother and sister. When she stepped back into the classroom, she was forty-five years old. Once she started to work again, however, she did not stop for thirtyone years. Sarah's first teaching assignment as a widow was in 1890 in Saline, Michigan, located south of Ann Arbor. She taught there at the high school level for several years before going to Manistee near Lake Michigan in 1893 where she taught one year of elementary school. She then crossed the great lake into Wisconsin and taught at several rural schools before returning to Michigan to teach in Newaygo and Ludington, both towns located in the western part of the state. ${ }^{26}$

Although successful in reviving her career, Sarah took additional steps to improve her circumstances by enrolling in the University of Michigan's teacher education program. ${ }^{27}$ She supplemented her high

\footnotetext{
${ }^{25}$ Sarah noted in her diary on board the Granada that Jack "gave me a copy of 'Burn's poems" and that she had spent "most of the time" with him while at sea. Many poems and letters from Jack also attest to an egalitarian spirit of endearment and passion typical of a companionate union. Sarah McComb, Diary, 18 April 1880, in author's possession; Jack McComb to Sarah Voorheis, 18 August 1880, file 35, carton 1; Jack McComb to Sarah Voorheis McComb, 7 January 1883, carton 1; Marriage license, 30 January 1882, Alameda county, California, file 96, carton 2, Keyes Papers. See also Rebecca L. Davis, "No Marriage at All, but Simple Harlotry': The Companionate Marriage Controversy," Journal of American History 94, no. 4 (March 2008): 1137-63.

${ }^{26}$ McComb, "Record of Teaching."

${ }^{27}$ The University of Michigan admitted women in 1870 and although many studied in professions such as medicine, dentistry, and pharmacy, "the vast majority of trained women" became teachers. Ruth Bordin, Women at Michigan: The "Dangerous Experiment," 1870s to the Present (Ann Arbor: University of Michigan Press, 1999), 21.
} 
school studies with university studies in "Latin, French, Spanish, Italian, German, English and Rhetoric, History, Philosophy, the Science and Art of Teaching, Math, and Drawing." 28 This wide array of courses typified the general curricula designed for women teachers, but the emphasis on modern languages separated it from a typical normal school curriculum. ${ }^{29}$ The rise of state normal schools and teacher colleges as well as coed universities meant better educated teachers and greater competition for open positions. School boards increasingly expected, and sometimes required, this formal preparation. In California in 1893, for example, 26 percent of teachers graduated from normal schools. By 1920, the proportion of California teachers with normal school educations increased to 72 percent, with an additional 8 percent of teachers graduating from colleges and universities. By 1930, a fouryear bachelor's degree was required of elementary school teachers. ${ }^{30}$ Sarah, graduating in 1894 with a Bachelor's of Letters and a Teacher's Diploma "for work done in the Science and the Arts of Teaching," prepared herself for the long run. ${ }^{31}$ Competitively credentialed at fortynine years old, she successfully made teaching a lifelong career.

Low wages, exacerbated by short school terms, dogged the profession, however. Regardless of a teacher's education and experience, the pay for teachers remained at subsistence levels. This situation caused a high rate of turnover and transiency, as teachers moved frequently for better paying positions. ${ }^{32}$ Records for a school in $W$ yoming show that twenty-nine teachers were employed over a twenty-three-year period from 1882 to 1905 , twenty-six of whom were single women earning wages between $\$ 40$ and $\$ 50$ a month for a three-month school term. Regional wage differentials also existed. A teacher in Montana in 1886 earned \$65 a month, while one in Kansas in the 1890s earned only \$30 a month. California, meanwhile, having enacted a pay equity law as early as 1874 , which required equal pay for male and female public school

\footnotetext{
${ }^{28}$ It is not clear how Sarah financed her education, but she likely benefited from her proximity to family in her home state and she also taught school in several Michigan towns during that time. Certificates of graduation and high school credits, file 114; McComb, "Record of Teaching;" Keyes papers.

${ }^{29}$ At the time of Sarah's enrollment at the University of Michigan, the state had one state normal school in Ypsilanti, founded in 1853. It became a state normal college in 1899 , five years after Sarah's graduation from the University of Michigan. Ypsilanti was unique for its courses in modern languages, in addition to preparatory courses typical of a normal school. The University of Michigan, however, had a champion for women in higher education in its president, James Angell, which may have contributed to Sarah's decision to enroll there, at the university level, instead of the normal school. Ogren, The American State Normal School, 88, 221; Bordin, Women at Michigan, 20.

${ }^{30}$ Weiler, Country Schoolwomen, 51.

31 "University of Michigan Teachers Certificate," file 87, carton 2, Keyes papers.

${ }^{32}$ Nancy Beadie, "Toward a History of Education Markets in the United States: An Introduction," Social Science History 32, no. 1 (2008): 47-73.
} 
teachers of the same rank, paid $\$ 60$ to $\$ 70$ per month at the turn of the century. In general, schools out West paid more than those back East. ${ }^{33}$

Sarah's record of teaching reflects this transient pattern of leaving short teaching stints and searching for better employment. She also ventured west where the pay was better. Her letters of reference, of which there were many since she worked for so many different school districts, frequently encouraged her aspirations. The principal of public schools in Newaygo stated in 1896 that while "the position is hers so long as she chooses to hold it, I recognize the fact that she is worthy of a better salary," adding that "I heartily recommend her for any high school position for which she may apply." 34 A similar letter from the superintendent of schools in Huron, South Dakota, in 1908, also acknowledged Sarah's underemployment when he said that while "I shall be sorry to lose her services ... . she is capable and worthy of a better position than I am able at present to offer her. Any board of education will be fortunate to secure her." 35 Sarah's mother also encouraged her daughter's ambitions in teaching. In a letter to Sarah in 1899, as Sarah continued to venture westward, she said that "I think it is the best for you to go to teaching again that will pay the best in the end." She also alluded to the better pay in western states, noting that "where you are now you ought get more salery[sic] than you have had here." Sarah's multi-lingual abilities, she felt, were also worth higher pay. As she said, "with your ability and the knowledge of the languages that you have you certainly ought to get a good position \& more wages." 36 Each time Sarah moved, as the letter from her mother and school supervisors suggest, her expectations must have been for a better position and higher pay.

By 1900, Sarah was in America's farthest frontier: Alaska. Her adventure in this Northwest Territory may have been the pinnacle of her career as she listed "taught the first school in Alaska" under her name in the 1920s alumni publication of the University of Michigan. ${ }^{37}$ She had helped establish the first school of seven students in Eagle City in

${ }^{33}$ Wyoming Territory also enacted a pay equity law but this did not necessarily ensure equal pay. Also, since the profession was increasingly dominated by women, wages for both women and men remained low. Glenda Riley, The Female Frontier: A Comparative View of Women on the Prairie and the Plains (Lawrence: University Press of Kansas, 1988), 122-3; Weiler, Country Schoolwomen, 39, 153; Charles E. Rankin, "Teaching: Opportunity and Limitation for Wyoming Women," Western Historical Quarterly 21, no. 2 (May 1990): 153, 158.

${ }^{34}$ A. W. Jones, Principal of Public Schools, letter of reference, 1896, file 94, carton 2, Keyes papers.

35 J. W. Smith, Co. Supt., Letter of Reference, 1908, file 94, carton 2, Keyes papers.

${ }^{36}$ Mrs. Voorheis (mother) to Sarah Voorheis McComb, 14 May 1899, carton 1, Keyes papers.

37"Who's Who in '94," University of Michigan Alumni, n.d., circa 1920s, file 113, carton 2, Keyes papers. 
1901. Local histories note that Sarah successfully convinced the School Board of 1902 to fulfill her requests for "needed items" in the "rented log cabin," including "school furniture, maps and textbooks from the States." Sarah also convinced the School Board to extend the school year to nine months, an important accomplishment in a profession made financially difficult with short school terms. ${ }^{38}$ Sarah, moreover, earned $\$ 100$ a month for her work, a substantial increase over the monthly wages she earned in the lower continental United States. Her status as a teacher, along with the extended school year, must have pleased her. ${ }^{39}$ She had earlier expressed overall satisfaction with Eagle City in letters home to her mother and sister, telling them how "Everybody says this is the nicest place on the Yukon River." "[E]very evening," she wrote, someone "drops in" to visit and she believed " $[t]$ here are the finest people I ever met here." 40

Although deep in Alaska territory, Sarah still lived within the bounds of proper womanhood. Unlike some of her adventurous peers, she did not seek teaching jobs at schools for Native Americans, but remained within white societies. ${ }^{41}$ In Eagle City, she lived amidst other white Americans - or European immigrants-seeking to reproduce the legal and social culture of their home states. Sarah likely met Debbie Wickersham, the wife of Eagle City's first judge, who played her part in establishing a society of elite white women. Within the first year of her arrival in 1900, Debbie "held her first afternoon tea for the ladies of the town." Her husband, Judge James Wickersham, not only presided over the establishment of a federal court house and jail, but attended to the norms of social propriety as well. By the end of his first year, he had "attended a ball at Fort Egbert ... dressed in formal attire including his swallow-tail coat." ${ }^{" 2}$ Living near a U.S. military outpost like Fort

${ }^{38}$ Elva Scott, Fewel on the Yukon: Eagle City (Eagle City, AK: Eagle Historical Society and Museums, 1997), 73; Elva Scott, Historic Eagle and It's[sic] People (Eagle City, AK: Eagle Historical Society and Museums, 1993), 114-5.

${ }^{39}$ The School Board also allocated \$15 per month for a school janitor, no small gesture to Sarah's middle-class status. Her successor for the 1904-1905 school year, Miss Lois Adams, was listed in Eagle City records as "teacher and janitor" for the same pay they had allocated to Sarah. Elva Scott, Eagle Schools Eighty Years, 1901-1981: Alaska Educational Systems in Action at Eagle, Alaska (Eagle City, AK: Eagle Historical Society and Museums, 1981), 18-24.

${ }^{40}$ Sarah McComb to Jennie Voorheis (sister) and Mother, Eagle, Alaska, 20 December 1900, file 36, carton 1, Keyes papers.

${ }^{41}$ Alaska established a dual system of education by 1900 whereby white children attended "Territorial schools," while "native" children attended underfunded schools run by the U.S. Bureau of Education. Frank Golder was a white man who spent three years teaching Aleuts in Unga, Alaska, at about the same time Sarah taught in Eagle City. Elva Scott, Eagle Schools Eighty Years, 13; Allen Wachhold, "Frank Golder as an Alaskan Teacher: 1899-1902," Alaska fournal 9 (1979): 38-42.

${ }^{+2}$ Scott, Fewel on the Yukon, 16. 
Egbert brought with it basic supplies and norms of propriety familiar to white Americans like Sarah. ${ }^{43}$ In one of her letters home, for example, Sarah mentioned an invitation to an evening reception at which she planned to recite poetry. As an educated teacher, she was welcomed into this elite society. ${ }^{44}$

Maintaining a reputation of proper white womanhood was an important job requirement for a female teacher as she not only needed good references from school boards and superintendents for future job appointments, but also for local and state teacher certifications. Sarah's numerous letters of reference praised her intellectual and teaching abilities as well as her character. When she graduated with her teacher's diploma from the University of Michigan, one of her professors wrote that "she is a lady of maturity, character and scholarship, well qualified in my opinion to do successful work as a teacher." The Newaygo school principal emphasized female virtues of submissiveness when he wrote that Sarah was "an ideal assistant able and willing to respond to my every suggestion." He also said she was "loved by her pupils and respected by her patrons," a fact reiterated by many of her references who knew that community support for a teacher depended on her reputation of good character. A teaching permit from the State of Washington attested that Sarah had filed "evidence of good moral character and personal fitness." The school board in Eagle City similarly gave their stamp of approval for Sarah's "competent and satisfactory" work..$^{45}$

Sarah followed her Alaska experience with an adventure to Cuba, only to return to the United States in 1903 to resume itinerant teaching in South Dakota, Washington, and California where she pursued an old-age strategy adopted by many wage earners: she worked as long as she could. ${ }^{46}$ Her teaching vita underscores her continued restlessness, however. She moved frequently from one teaching job to another,

${ }^{43}$ The U.S. Army established a presence in Alaska following the purchase of the territory from Russia in 1867. Gold discoveries in the 1890s intensified the military's presence in the Alaskan interior. Army posts included Fort Egbert in Eagle City, completed in 1899 shortly before Sarah's arrival. Scott, Fewel on the Yukon.

${ }^{44}$ Sarah McComb to Jennie Voorheis (sister) and Mother, Eagle, Alaska, 20 December 1900, file 36, carton 1, Keyes papers.

${ }^{45}$ Letters of reference from B. A. Hinsdale, Professor, University of Michigan, 3 April 1894, file 94; A. W. Jones, Principal of Public Schools, Newaygo, Michigan, 1896, file 94; Common Schools of the State of Washington, Stevens County, 14 October 1912, file 88; School Board, Eagle, Alaska, 22 June 1903, file 94; carton 2, Keyes papers.

${ }^{46}$ Roger Ransom and Richard Sutch, "The Labor of Older Americans: Retirement of Men On and Off the Job, 1870-1937," Fournal of Economic History 46, no. 1 (March 1986): 1-30; Roger Ransom and Richard Sutch, "The Impact of Aging on the Employment of Men in American Working-Class Communities at the End of the Nineteenth Century," in Aging in the Past: Demography, Society, and Old Age, eds. David I. Kertzer and Peter Laslett (Berkeley: University of California Press, 1995), 303-5; Daniel Scott Smith, "Life Course, Norms, and the Family System of Older Americans in 1900," Fournal of Family History 4, no. 2 (Fall 1979): 285-98. 
sometimes teaching at more than one school in a year; in California she taught in seven different school districts over a period of five years. Unlike her earlier teaching positions that were often at the high school level, she now taught only at the elementary level in rural towns where turnover was common. ${ }^{47}$ There is no indication that she encountered employment problems as she continued to collect good letters of reference, but she likely faced challenges due to age. She taught until she was seventy-six years old in $1921 . .^{48}$

By this time, teaching had grown into a profession of women determined to gain public recognition for their work. Women's retirement, once confined to pockets of concern in urban cities, became a matter of growing public concern. Abraham Epstein's 1922 report on the status of teachers' pensions noted that while the number of pension systems increased over the previous decade, many of these systems required a more "equitable and sound financial basis." Stiff longevity requirements-ranging from twenty to thirty-five years of serviceoften barred teacher participation. ${ }^{49}$ California's teacher pension plan, established in 1913, depended on teacher contributions and required that one teach "for at least thirty school years," half of which had to be in California, including the last ten years before retirement. ${ }^{50}$ Young female school teachers had founded clubs throughout the state to give women a voice on these issues. These women-increasingly single, childless, career teachers-worried about their income. At the 1919 annual party of the Oakland Schoolwomen's Club, this younger generation of teachers performed a "Pageant to Pensions" skit with the theme "Motivation of Higher Salaries." 51 Sarah was likewise concerned. She compiled her "Record of Teaching" that, by her own calculations of the actual school years and months taught by 1920, totaled twentyeight years in the classroom, five of which occurred in California. ${ }^{52}$ She also owned a copy of the 1927 edition of California's "Teachers' Retirement and Salary Law," but she never qualified for the program. ${ }^{53}$

Teaching granted women like Sarah independence, individual expression, and adventure within the limits of proper womanhood, but it

${ }^{47}$ Teaching positions were located in Sonoma, Lake, Shasta, Mariposa, Modesto, Ruth, and Colusa counties. McComb, "Record of Teaching." A printed calling card identified Sarah as a teacher of "High School Branches" and "Modern Languages." n.d., file 106, carton 2, Keyes papers.

${ }^{48}$ McComb, "Record of Teaching."

${ }^{49}$ Epstein, Facing Old Age, 189.

50"An act to provide for the payment of retirement salaries to public school teachers of this state," Statutes of California 1913, Chapter 694: Fortieth Session of the California Legislature (Sacramento: Chief Clerk of the Assembly, 1913), 1427.

${ }^{51}$ Weiler, Country Schoolwomen, 39, 49, 22, 153, 56.

${ }^{52}$ McComb, "Record of Teaching."

${ }^{53}$ California State Department of Education, 1927 Edition of Circular of Information Regarding Teachers' Retirement Salary Law, file 77, carton 2, Keyes Papers. 
did little to advance their financial position. Although Alaska was probably Sarah's best situation monetarily, the cost of living in the territory likely eroded her real wages. ${ }^{54}$ In a profession with little recognition for experience or pay raises for work well done, it is not surprising that Sarah continuously searched for something more. Teaching sustained her independence while she worked, but it never paid enough to save for later.

\section{The Market Economy}

As Sarah approached her mid-fifties, she boldly entered into business schemes that promised to supplement her teaching income. It is difficult to determine how typical Sarah was in this regard. Anecdotal evidence from teacher narratives suggests that some single women teachers did pursue entrepreneurial profits, but how many did so-and to what degree of success-is an underexplored area of research. Yet, evidence gleaned from extant studies suggests that single women teachers engaged in commerce. Mary Cordier, for example, describes how a single female teacher in Nebraska bought and sold parcels of land and accumulated some acreage in the late nineteenth-century. Chris Enss documents Bethenia Owens-Adair's remuneration from farm work and sewing as she worked as a teacher and furthered her education. ${ }^{55}$ It is likely that many single teachers sought ways to improve their economic circumstances.

One of Sarah's early money-making efforts occurred in Alaska and involved the plucky labor of homesteading. "Last month," she wrote to her mother and sister from Eagle City, "I staked the vacant lot next to mine for I thought it would come handy-but two brothers staked it too and got their logs on first, but I did not know it." ${ }^{56}$ Undeterred, she pursued another opportunity in Eagle City, which she hoped would "make more than a state sum." $"$ This time, however, the work was very familiar to her as a woman: laundry. ${ }^{58}$ As Sarah said to her sister and mother, "I have started in a new business, and you never would guess what it is. So I might as well tell you from the start." Explaining that

${ }^{54}$ The cost of shipping textbooks to Eagle City from the contiguous states, for example, involved paying a local businessman a "warrant of $\$ 150$ " to purchase and ship the goods while on a business trip "outside." Scott, Historic Eagle, 114-5.

${ }_{55}^{5}$ Cordier, Schoolwomen of the Prairies and Plains, 183; Chris Enss, Frontier Teachers: Stories of Heroic Women of the Old West (Guilford, CT: Globe Pequot Press, 2008).

${ }^{56}$ Sarah McComb to Jennie Voorheis (sister) and Mother, Eagle, Alaska, 20 December 1900, file 36, carton 1, Keyes papers.

${ }^{57}$ Ibid.

${ }^{58}$ Michael Bargo identifies the laundry business as one of many entrepreneurial efforts by women in the West. Michael Bargo, "Women's Occupations in the West in 1870," Fournal of the West 32, no. 1 (January 1993): 30-45. 
"the young man for whom I was cooking was in the laundry business," she went on to describe how poorly he fared in his endeavor. "He had more work than he could do," Sarah wrote, "but the poor fellow did not understand his business, and he kept getting worse and worse in debt lost his custom[ers] and managed very poorly." After hiring Sarah and a Miss Whitaker to help him with the ironing, he sold the business to Sarah for \$150. "After due consideration," Sarah said, adding that she had also secured the laundry business of the local soldiers stationed there, she accepted the offer. Her plans went further, as she also "bought a cabin across the street for $\$ 75 \ldots$ to fix up as the wash house and dry room" while using her own cabin for "ironing and living." 59

Sarah carefully dressed her enterprise in the cloak of propriety. Proper white women did not ordinarily do the work of a washer woman, but they certainly supervised others. Sarah presented her business in this light. She told her family that she had a partnership with Miss Whitaker because "She can iron starched clothes such as shirts \&c beautifully," and she said she employed the labor of a young soldier to "come in and do all the hard work... [such] as working the washing machines, bringing in wood and tending to fires \&c." Although she also said she would do ironing and sort the clothes, she emphasized the hired labor for the business, carefully construing her role as a proper white middleclass woman directing the domestic operations of others. "So we three," Sarah wrote in a light-hearted assurance to her mother and sister, "are running the only public laundry in Eagle City." 60

Sarah's motivation was financial. As she said, "We laugh over it and think it is comical enough for us [to be in the laundry business], but we are going to make money." Explaining that she "like[d] the business element in it," she expected to "take in about $\$ 300$ a month and it will be more every month." It is "alluring," she wrote, "to think we may make more than a state sum." Should the laundry business sound too unsuitable to her mother and sister, she noted that she still had her old standby available to her: teaching. "I have a French class too twice a week of four and a Spanish class which I shall begin after Xmas." "So you see," she concluded, "I am as busy as a bee from morning till night or bed time and I like it ever so much." 61

Sarah's enterprise in laundry did not leave her financially prosperous. ${ }^{62}$ When the public school opened in 1901, Sarah secured the

${ }^{59}$ Sarah McComb to Jennie Voorheis (sister) and Mother, Eagle City, Alaska, 20 December 1900, file 36, carton 1, Keyes papers.

${ }^{60} \mathrm{Ibid}$.

${ }^{61}$ Ibid.

${ }^{62}$ It is not clear why Sarah gave up her laundry business, but she may not have fully accounted for the hard labor and the costs involved, including two other employees. 
position at one-third the monthly pay she expected to receive from her laundry business. Her unrealized expectations for an entrepreneurial profit may explain why she left Alaska for Cuba in December 1903, when she was fifty-eight years old. Because Cuban real estate looked promising, she ventured there to seek her fortune. She sought not a better teaching position-her job in Alaska was a good one-she sought a profit in real estate.

Sarah exuberantly explained her plans to her sister in a letter written en route to the island: "I have become acquainted with a lady who is going to Cuba with her husband and two children. He has been there 1 year and is buying land \& selling it. In three months land has doubled," she said. "Many Americans are going in now \& will be."63 Sarah had caught land fever in the newest of America's imperial ambitions following the Spanish-American war. ${ }^{64}$ Unlike many of her female contemporaries involved in reform, her goal was not to teach, proselytize, bring the vote to women, or in other ways "civilize" American territorial interests. Rather, she wanted to make money. "Those who have bought land could sell it for twice as much as they paid for it," Sarah explained. "If everything goes as promising as it looks now, we are in a good thing." 65

Upon her arrival in Cuba, however, Sarah found difficult conditions that challenged her sense of propriety. She had a rough start, as her "trunk did not come" and she was in "dirty clothes" and "so sticky and uncomfortable." "It is no place for you or anyone who wants comfort to come here," Sarah wrote to her sister from Santa Domingo. "If things had been brought which are needed it would be much better. There isn't a tea kettle in town. We heat water for tea, coffee \& such in an open kettle (no lids) and as the smoke just pours out of the stove you may know how pure it is." Cooking also frustrated her. "We can't bake anything decently for the stove doesn't work. In fact there is not any kind of a comfortable (or even possible to get along without) outfit." Uncharacteristically, she complained: "I was much more comfortable

She also likely faced stiff competition from other proprietors, such as Anna Malm, a Finnish immigrant recorded in a local history as the owner of "Arctic Laundry," which she operated soon after her arrival in Eagle in 1898. Scott, Fewel on the Yukon, 46.

${ }^{3}$ Sarah McComb to Jennie Voorheis (sister), en route to Cuba, 20 December 1903, file 36, carton 1, Keyes papers.

${ }^{64}$ For more on the Cuban land market, see Carmen Diana Deere, "Here Come the Yankees! The Rise and Decline of United States Colonies in Cuba, 1898-1930," The Hispanic American Historical Review, 78, no. 4 (November 1998): 729-65; Juan C. Santamarina, "The Cuba Company and the Expansion of American Business in Cuba, 1898-1915," The Business History Review, 74, no. 1 (Spring 2000): 41-83.

${ }^{65}$ Sarah McComb to Jennie Voorheis (sister), en route to Cuba, 20 December 1903, file 36 , carton 1 , Keyes papers. 
in Alaska." ${ }^{66}$ An additional difficulty in Cuba was that, unlike Alaska, it lacked a federal military presence to help create a white middle-class society; it was not part of the American frontier. American railroad corporations nevertheless made investments in this plantation economy but without U.S. military protection. ${ }^{67}$ They created towns with familiar names such as Jacksonville, Lincoln, and "Omaja," but Sarah did not find the comfort of white settlements that she had grown accustomed to in the corners of America's conventional frontier. ${ }^{68}$ Limited in funds and finding little status in her position, she struggled to find any redeeming value for her efforts.

Instead of getting rich, Sarah faced greater poverty than ever before. By the time she arrived in Cuba, the real estate market had risen considerably. She did not have enough money to enter into a joint ownership plan to buy land with the Wards, a Michigan family that she had met. To support herself she worked for her board at the Wards' home that was on a plantation, doing housework and serving as the resident interpreter. In contrast to her excitement in Alaska, her letters to her sister now carried a deep note of frustration. Not only did she feel overworked in domestic labor- "Mrs. W[ard] \& I do the work of course, [though] she is not much of a hand"-but her work as an interpreter was frequent and unremunerated. "It is hardly worthwhile to work here for my board as I am doing now," she wrote. "I have to interpret everytime anybody comes, which is everyday more or less. I have no trouble in that at all ... [but] I shall not stay here if I can't make some financial arrangements." 69

Sarah's search for subsistence work as a teacher-her standby profession-was unsuccessful. Stranded on the plantation outside of town, she struggled to find students. "Two young men that I have seen said they would take lessons," she wrote hopefully. "One is Georgian a perfectly 'charming' young man who wants to learn Spanish, has been here a year, has a Cuban wife." The other potential student was "a Spanish young man who does our errands \&c who wants to learn English." But, "whether they would want to pay me enough is the question." The conditions for a classroom and more students were bleak: "I don't see how I could give lessons here on the place. I should have to hire a room in town, and walk there everyday in the road or ride a mule,

\footnotetext{
${ }^{66}$ Ibid.

${ }^{67}$ Although many American investors anticipated U.S. military protection for their investments in Cuba, they never saw it materialize as such. Santamarina, "The Cuba Company."

${ }^{88}$ Deere, "Here Come the Yankees!" 729-65.

${ }^{69}$ Sarah McComb to Jennie Voorheis (sister), Cuba, 25 December 1903, file 36, carton 1, Keyes papers.
} 
neither of which I want to do," she confessed. ${ }^{70}$ When she wrote to her sister less than a month later, she was fed up with her situation. "I am simply disgusted and have given up trying to teach here... I am going to Havana and see about a position in school there." But this plan had its own pecuniary risks: "I have two twenties which will take me there," Sarah wrote. "I think I had better go for I don't believe there are enough [students] here to pay me." But "[i]f I don't get anything to do," she said in what must have been a bitter pill to swallow, "I shall have to depend on you for money to return [to the United States]."

Cuba was not the lucrative opportunity Sarah expected. She conceded to her sister that "to tell the truth, I never was so homesick in my life... The climate is delightful and no mistake, but one can't live on air...." Not only did she fail to finance her future independence as she aged, she barely earned her daily keep. From this vantage point, teaching for subsistence pay in the United States was better than the poverty she endured in Cuba. "If I once get out of this," she wrote, "I'll be contented to take a position in the States and jog along the same as before." Yet, she had believed she "was going to do well" and "make money" in Cuba. "My desire for something more led to this trip," she wrote, "and tho it may be all for the best yet I can't see it now." 72

Sarah nevertheless continued to hope for something more. When she returned to the United States to teach, she still sought schemes to make money. In 1917, when she was seventy-two years old, she bought several lots underwater in California's Monterey harbor, which the seller claimed would soon be filled and developed. She paid a deposit of $\$ 30$ and committed to paying $\$ 8$ a month for the balance of a $\$ 400$ purchase. This $\$ 8$ was her single largest expense each month after rent. ${ }^{73}$ When she inquired about selling the property fifteen years later, an eighty-five-year-old Sarah learned that "while the Brookwater [property] is now being constructed, there is no market nor money to buy right now...." Any plans she had of turning a profit were dashed. ${ }^{74}$ This was also true of some property she apparently held in South Dakota and Michigan, which never appreciated in her lifetime. Not selling any of this land, she kept it until her death, leaving

\footnotetext{
${ }^{70}$ Ibid.

${ }^{71}$ Sarah McComb to Jennie Voorheis (sister), Cuba, 13 January [circa 1904], file 36, carton 1, Keyes papers.

${ }^{72}$ Ibid.

${ }_{73}^{73}$ Contract for Deed, 3 March 1917, file 79, carton 2, Keyes papers.

${ }^{74}$ Reply from Mr. Harris, Monterey, written on letter Sarah McComb wrote to him in 1932, file 36, carton 1, Keyes papers.
} 
the property in her will to two nieces. ${ }^{75}$ In the end, these ventures in the market economy gave her nothing but hope for a financial windfall.

\section{The Family Economy}

The traditional family economy was Sarah's last chance for old-age income. For single, unattached women, calling on extended kin for support was no easy proposition. In their study of widows in the northeast, Tamara Hareven and Peter Uhlenberg identify the various living situations old women faced in the early twentieth century. Married women typically carried their economic dependency as wives into their old age, becoming dependent on the earning power of their husbands. Widowed women with children likewise depended on traditional family support, often having an adult child living with them to provide household help and economic assistance. A single woman who never worked or married likely began living with kin early in life so that, as she aged, a pattern of co-residency with family was already established. Single, childless women who had worked, however, had to pursue other living arrangements. Such women in Hareven and Uhlenberg's study of widows turned to their own siblings, nieces, nephews, or surrogate kin for a place to live. If no arrangement could be made, they lived their last phases of life alone, dependent upon donations from extended family and public charities. ${ }^{76}$

For Sarah, calling on kin for help created undue stress. She had two brothers, but she turned to Edward in California who was the more prosperous and better positioned of the two men. When he ventured to Sutter Creek in 1877, he married a propertied widow and successfully profited from the gold and tungsten mining industries. He achieved some status as a California State Senator from 1890 to 1898 when he chaired the Senate Finance Committee and served on committees related to mining. He retired in 1918 at sixty-eight years of age with extensive California land holdings in Amador County, several properties in San Francisco, and a summer home at Lake Tahoe. The booms and busts of capitalism followed him into retirement but he managed to

${ }^{75}$ It is not clear how or when Sarah acquired this property. "Last Will and Testament of Sarah E.V. McComb," 17 February 1928, file 93, carton 2, Keyes papers; Booklet from Central National Bank, Oakland, file 78, carton 2, Keyes papers.

${ }^{76}$ Tamara K. Hareven and Peter Uhlenberg, "Transition to Widowhood and Family Support Systems in the Twentieth Century, Northeastern United States," in Aging in the Past: Demography, Society, and Old Age, 273-299. 
stay afloat, remaining active in financial and mining circles as well as in many fraternal organizations. ${ }^{77}$

Edward supported women in both his immediate and extended family who met traditional definitions of female dependency. He was generous with his wife and spoiled his daughter and grandchildren who lived in a house next door to his in Sutter Creek. He also supported his mistress and her mother with a home in San Francisco. Of his extended female kin in Michigan, he supported his mother and younger sister Jennie who remained unmarried and dedicated to the care of their mother. Edward's financial commitment was sometimes uneven, but he did not balk at this patriarchal responsibility. In a letter to Jennie in August 1908, for example, he wrote that "I just returned from Lake Tahoe last evening and found your letters awaiting me." Jennie had written more than once to appeal for money, an indication of her sense of urgency, but Edward casually responded that he "had it in my mind that I had sent you some money before I left home but I guess I did not do it." He now enclosed a check for $\$ 100$ and outlined his plans to return to Lake Tahoe lest she expect to hear from him again soon. On another occasion, before he left on a journey to China, Japan, and the Philippines in 1910, he sent Jennie a check for \$200, telling her to "get yourself a Christmas present." Although he probably underestimated the extent of her needs, there is no hint of resentment on his part. Likewise, when he later learned that another female dependent, "Aunt Mary," was with Jennie and likely benefitting from his largess, he wrote "I am glad" and "we all send love to her," a sentiment he expressed again several months later when he sent another $\$ 100 .^{78}$

Sarah did not receive this welcome of support from Edward for her old-age needs. Her relationship with him, often uneasy, was fraught with money problems made more difficult by her hard-earned independence. This tension was most noticeable when she was stranded in Cuba and needed money to return to the United States. Rather than appeal to Edward directly, she asked Jennie for help. But Jennie had recently tapped Edward's goodwill; the timing was not right. As Sarah wrote to Jennie from Cuba, "I should think you would hear from Ed but I am afraid you are not going to have any more from him." The prospect of contacting Edward herself was not appealing. "I thought I would write to Ed," she said, "but I don't feel much like it." She decided, however, that given her dire circumstances, "If I can't do any other way," she would leverage her small land holdings as collateral for money from

${ }^{77}$ Obituary, Amador Ledger, 7 May 1925; Mary Clark Gibbons, granddaughter of Edward Voorheis, interview by author, San Francisco, 16 February 1992.

${ }^{78}$ Edward C. Voorheis to Jennie Voorheis, 10 August 1908; 7 November 1908; 24

November 1910. Edward C. Voorheis to Aunt Mary, n.d.; carton 7, Keyes papers. 
Edward. "I am going to let him take the land as security," she wrote to Jennie, adding that "of course he would [take it] anyway." Although it is not known exactly how Sarah solved her financial problems in Cuba, it is clear that she was distraught over money and distressed about her dependency on her brother. She wished that her "prophesied legacy" would come through: "I never wanted it worse," she wrote to her sister. $^{79}$

Sarah nevertheless depended on her brother for the last twenty years of her life. When she returned from Cuba and resumed her work as an itinerant teacher, she had no alternative plan for old age when she could no longer work. Her brother's support, however, was not inevitable; Sarah garnered his help through sheer persistence. Her initial visits and letters of request in 1919 were rebuffed. "Your letters sent to the office were sent out to the house unopened," Sarah learned in a letter from her brother's second wife (and former mistress) Frances Voorheis. "Do you ever stop to realize the many calls [Edward] has upon his earning capacity?" she wrote. "There are not many brothers or sisters who respond to their kin call as he has," she said. Finally, however, they arranged to provide Sarah with $\$ 50$ a month, "until you are able to do something for yourself," Frances wrote to the aging school teacher ${ }^{80}$ Dependent upon Edward, Sarah had little choice but to endure this condescension. "If you wish [Edward] to continue sending you this amount," Frances advised, "do not go to his office. If you do he will not see you and it will work havoc for you." ${ }^{81}$ Sarah likely chafed at the resentful tone in this letter, and in 1920 she secured one more teaching position in San Luis Obispo. When the school year ended in 1921 , she was seventy-six years old and at the end of her career; there is no evidence that she taught again. ${ }^{82}$ Edward balked at his responsibility to Sarah, but, by her own desperate insistence, she successfully became one of his female dependents.

Sarah leveraged her status as a proper woman teacher to claim support from the financial patriarch of her family; she appealed to her brother's sense of filial duty. Having carefully maintained her reputation for her race and class while an itinerant teacher, she could insist that Edward fulfill his part for an unmarried sister in need. Her entitlement, however, came with the subordinate status of dependency that left Sarah treated like a wayward child. Edward seemed willing to support women who met traditional definitions of female dependency,

\footnotetext{
${ }^{79}$ Sarah McComb to Jennie Voorheis (sister), Cuba, 13 January [circa 1904]; Sarah McComb to Jennie Voorheis (sister), on letterhead "Santa Clara Fruit and Cotton Co. Plantation, Santa Domingo, Cuba," n.d. [circa 1904], file 36, carton 1, Keyes papers.

${ }^{80}$ Frances Voorheis to Sarah McComb, 31 January 1919, carton 1, Keyes papers.

${ }^{81}$ Ibid.

${ }^{82}$ Teaching experience in California listed in "Affidavit of Applicant for Life Diploma," 8 September 1924, file 84, carton 2, Keyes Papers.
} 
but he was not pleased about Sarah. She was an educated, well-traveled teacher who had married for companionship, not money, and she had joined the first generation of women who practiced economic and social independence. ${ }^{83}$ Edward, meanwhile, denied a college education to his daughter, left his first wife at home when he traveled abroad, and expected her to remain subordinate while he spent vacations at Lake Tahoe with his mistress. ${ }^{84}$ When Sarah became dependent upon him, she brought an outsized personality shaped by a culture of female autonomy and independence to what must have been a stifling expectation of female behavior. She endured a loss of status out of pure need for subsistence in her old age.

Sarah meticulously listed her monthly "receipts from Ed" in various notebooks along with her "self acct" that included basic items such as "coal $\$ 4.90$, wood $\$ 1.15$, stockings $\$ .79$, and toothbrush $\$ .10$," but also a few extras that she no doubt valued: "carfare $\$ .12$, shows $\$ .42$, examiner [newspaper] \$.90, cheese $\$ .10$, lamb $\$ .15$." Every once in a while she would record additional income from another niece, Lillian Carter, who was her sister Ella's daughter. Carter apparently sent what she could afford as amounts varied from $\$ 5$ to $\$ 40$. Her contributions reveal the informal web of support among those in need. Sarah likewise shared what little she had with others, recording small amounts given to people poorer than herself, such as 75 cents to someone named Mattie or a dollar to a man named Arthur. Written in the hand of a very old person, these small tokens of assistance likely went to the other elderly residents of her boarding house. ${ }^{85}$ For many people like Sarah, old age brought impoverishment despite hard work in their most productive years.

\section{Conclusion}

Sarah survived Edward by eleven years. ${ }^{86}$ Living marginally as a boarder in San Francisco, she wrote in her diary that "I refuse to believe in the

${ }^{83}$ For discussion about a woman teacher's challenge to traditional patriarchal constructs, see Jackie Blount, "Spinsters, Bachelors, and Other Gender Transgressors in School Employment, 1850-1990," Review of Educational Research 70, no. 1 (Spring 2000): 83-101; White, The New Women Teachers Come Along, 68-71.

${ }^{84}$ Gibbons, interview by author. Edward may have resented the fact that Sarah's husband had not provided for his widow, that Sarah had married for love not economic security, that she had pursued individual interests and travel outside the norms of traditional womanhood, or some combination of these challenges to traditional patriarchal order.

${ }^{85}$ Sarah McComb, savings account books, circa 1915-1929, files 76, 78, carton 2, Keyes papers.

${ }^{86}$ Edward died in 1925 , leaving property to his daughter who continued to support his many female dependents. Obituary, Amador Ledger, 7 May 1925; Memo "Enclosed please find check to your order for \$50" from Baylies Clark (husband to Edward's daughter), 1929 to 1936, carton 1, Keyes Papers. 
reality of lack or poverty." ${ }^{87}$ Yet, poverty was a reality with which to contend. To cope, she took solace in spiritual adages and words of wisdom. Her sense of spirituality had always been present in variant forms-she had transferred her membership in the Westminster Presbyterian Church of Grand Rapids to the First Presbyterian Church of San Francisco upon her marriage in 1882, and over the years she often consulted fortune tellers and the occult for prophesies-and now, at ninety years old, she sought spiritual guidance for problems in old age. ${ }^{88}$

Poverty, and the dependent status that it put her in, likely exacerbated the stomach ailments and anxiety that Sarah complained about with greater frequency as she grew old. In one diary entry she wrote "my understanding is established in spirit, I know the relation between mind and body; between thought and substance. I agree with what I eat and what I eat agrees with me." She eased her anxiety by writing "I am at peace with all men and all things. I do not resist nor antagonize anybody nor anything," and she strengthened her resolve to endure her indigestion when she said "My stomach is wise, strong and energetic, and I always think and speak of it as capable in every way of doing the work given it to do." Struggling in her last days, she wrote that "I am now free from fear, anxiety, worry, dread and suspense. I have faith in and trust the Holy Spirit to protect me, to provide for me, and to bring all my affairs into divine order." ${ }^{89}$ Yet, she understood the gendered construct of her life when she wrote that "To get to beget is the life of man, to suffer the strong is the life of woman." 90

Sarah's biography provides a window on the problem of old-age income for single women teachers. They could support their independence through work, but low wages as well as short school terms made it virtually impossible to save for retirement. Profit from market ventures, furthermore, proved elusive. Sarah was neither skilled nor educated in the male-dominated arena of business, and as a teacher moreover, she could not afford to seriously challenge gendered norms of behavior often required for business success. Yet for single, unattached women, it was increasingly difficult to rely on extended kin. Recognizing this problem, urban teachers in major cities began to organize collectively for pensions. Older women in smaller rural schools scattered throughout the country took individual action, teaching as long as possible,

${ }^{87} \mathrm{McComb}$, Diary (poems written in handwriting of her old age on scraps of paper, inserted in Diary, undated), in author's possession.

${ }^{88}$ Letter of certification from Westminster Presbyterian Church, Grand Rapids, Michigan, 30 August 1882, carton 1; Horoscope chart from the "Rathill's Academy of Occult Sciences," New York, addressed to Mrs. Sarah E. V. McComb, Eagle, Alaska, file 91, carton 2, Keyes papers.

${ }^{89}$ Little Notebook, n.d. [circa 1936], file 97, carton 2, Keyes papers.

${ }^{90} \mathrm{McComb}$, Diary, in author's possession. 
and engaging in entrepreneurial activities before turning to the family economy for help. Through Sarah's experience, this article highlights the challenges they faced.

Sarah's experience also contributes to historical discussions about the welfare state, illustrating Brian Gratton's contention that intrafamilial tensions intensified in the early twentieth century, which in turn fueled the growing acceptance of a federal social security program. Men, growing weary of supporting a long list of dependents with a system that "personalized the retirement tax," increasingly embraced the idea of a collective responsibility for old-age dependents. ${ }^{91}$ The tensions evident between Sarah and her brother over her old-age needs may not have been unusual in the years leading up to the New Deal and the social security program. Sarah's financial straits upon retirement from teaching also anticipated the problems faced by the next generation of working women who lost their jobs in the Great Depression. Elaine Abelson identifies this onset of a "new poor" of white, educated, unattached women in the 1930s, who faced unemployment without savings or close kin. Although these women found independent means while they worked, they experienced poverty and dependency once forced out of work. ${ }^{22}$ This phenomenon was already experienced by the autonomous, self-supporting women of the previous generation like Sarah. Rather than the possibility of continuing independence into old age, Sarah faced poverty and dependency. In order to plan for retirement, she needed wages equal to men, a teacher's pension, and the privilege of saving for her continued autonomy as an old woman. For this she would have to await a transformation in the ideals of economic fairness, a change that would come too late for the first generation of independent women.

${ }^{91}$ Brian Gratton, "The Poverty of Impoverishment Theory: The Economic WellBeing of the Elderly, 1890-1950," Fournal of Economic History 56, no. 1 (March 1996): 57-58; Carole Haber and Brian Gratton, Old Age and the Search for Security: An American Social History (Bloomington, IN: Indiana University Press, 1994).

${ }^{92}$ Elaine S. Abelson, "Women Who Have No Men to Work for Them': Gender and Homelessness in the Great Depression, 1930-1934," Feminist Studies 29, no. 1 (Spring 2003): 104-27. 